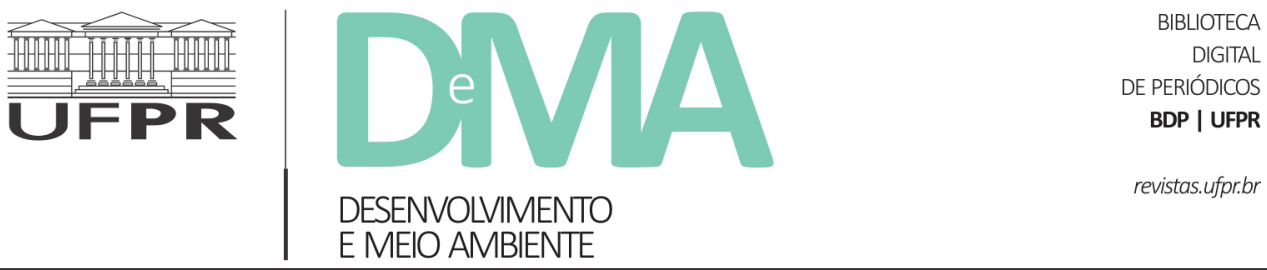

\title{
Environmental governance and social learning: towards more reflexive interactions
}

\section{Governança ambiental e aprendizagem social: por interações mais reflexivas}

\author{
Pedro Roberto JACOBI ${ }^{1 *}$, Daniele Tubino de SOUZA ${ }^{2}$ \\ ${ }^{1}$ Universidade de São Paulo (USP), São Paulo, SP, Brasil. \\ ${ }^{2}$ Universidade do Vale do Rio dos Sinos (UNISINOS), Porto Alegre, RS, Brasil. \\ *E-mail de contato: prjacobi@gmail.com
}

Article received on January 7, 2021, final version accepted on April 26, 2021, published on December 21, 2021.

ABSTRACT: Facing the increasing complexity of social and environmental issues, environmental governance configurations are required to adopt increasingly collaborative strategies and reflexive learning oriented practices. The goal of this paper is to present a theoretical discussion about environmental governance and the contribution of the social learning approach to expand the reflexivity potential of multi-stakeholder interaction spaces in governance processes. We argue that social learning practices, understood as interactive and reflective, can broaden the critical responsiveness of participating in environmental governance systems. Social learningoriented processes are based on the promotion of dialogic spaces in which participants can learn from the diverse views present in the group and critically reflect on the assumptions that underlie decision making, thus creating possibilities for the emergence of innovative practices and new social configurations. We conclude that social learning processes driven by the stakeholders interactions in environmental governance spaces tend to broaden the ability of participants to critically evaluate the governance structure itself, in order to foster arrangements that can effectively promote practices for sustainability.

Keywords: governance; environmental governance; reflexivity; social learning; dialogue.

RESUMO: Diante da crescente complexidade das questões socioambientais, as configurações de governança ambiental são solicitadas a adotar estratégias cada vez mais colaborativas e práticas orientadas para a aprendizagem reflexiva. O objetivo deste artigo é apresentar uma discussão teórica sobre a governança ambiental e a contribuição da abordagem da aprendizagem social para ampliar o potencial de reflexividade dos espaços de interação entre múltiplos stakeholders nos processos de governança. Argumentamos que as práticas de aprendizagem social, entendidas como interativas e reflexivas, podem ampliar a capacidade de resposta crítica dos atores 
que participam dos sistemas de governança ambiental. Os processos orientados para a aprendizagem social baseiam-se na promoção de espaços dialógicos em que os participantes podem aprender com as diversas visões presentes no grupo e refletir criticamente sobre as premissas subjacentes às tomadas de decisão, criando, assim, possibilidades para o surgimento de práticas inovadoras e de novas configurações sociais. Concluímos que os processos de aprendizagem social impulsionados pelas interações entre stakeholders nos espaços de governança ambiental tendem a ampliar a capacidade dos participantes de avaliar criticamente a própria estrutura de governança, a fim de fomentar arranjos que possam efetivamente promover práticas para a sustentabilidade.

Palavras-chave: governança; governança ambiental; reflexividade; aprendizagem social; diálogo.

\section{Introduction}

One of the most pressing issues for the contemporary environmental debate in the governance of the Earth system is the institutional architecture that can enable the increase of the adaptive capacity and resilience of ecosystems. The worsening of socio-environmental capacity, notwithstanding the expansion of governmental and non-governmental activities to expand access to information and education to deal with the incidence and intensity of natural disasters and their impacts, requires increasingly collaborative strategies and reflective learning-oriented practices.

In this direction, we propose a theoretical discussion about the capacity of social actors and institutions to think critically about their own performance and reformulate their objectives, practices and values to navigate with wisdom within human, social and environmental complexity. We argue that the co-production of knowledge must necessarily consider the interrelationships of the natural environment with the social domain, including an analysis of:

(1) the determinants of processes and actions focused on producing solutions for socio-environmental sustainability;
(2) the role of the different actors involved; and

(3) the dynamics of the different forms of social organization that enhance the strength of these processes.

Within this understanding, the themes of environmental governance and social learning constitute important theoretical references to advance towards the creation of reflective, collaborative and participatory arenas to face socio-environmental challenges in a context of increasing complexity and uncertainty.

Environmental governance is recognized as a coordinated action that requires social participation through multi-stakeholder engagement and negotiation; it is based on the empowerment of the social actors involved and the management of natural resources through conflict resolution mechanisms (Lemos \& Agrawal, 2006). Reflexivity in this context can be defined as the "the ability of a structure, process, or set of ideas to reconfigure itself in response to reflection on its performance" (Dryzek \& Pickering, 2017, p.1). Social learning, in turn, is related to collective learning processes based on dialogic interactions that take full advantage of the diversity present in a group to promote the transformation of mindsets and values under- 
lying decision-making so that innovative solutions towards sustainability might emerge (Wals, 2007).

The aim of this paper is therefore to discuss the topic of environmental governance within the context of reflexivity and to connect this topic with the social learning approach in order to deepen and understand the interactive spaces between different stakeholders within these processes. In line with scholarly research in the field of social learning (e.g. Röling, 2002; Wals et al., 2009; Medema et al., 2014; Souza et al. 2019), we observe such a learning a process as involving with specific characteristics aimed at provoking critical thinking among multiple actors, leading them to individually and collectively challenge their own assumptions and beliefs in order to create the means to bring about innovative perspectives and solutions to socio-environmental issues. In this sense, we argue that social learning provides an approach and a semi-structured framework that can empower environmental governance configurations towards a more reflective stance.

\section{Environmental governance within a context of reflexivity}

Governance is an increasingly frequent term in economic discussions, in debates related to questions about the role of the state, and has been repeatedly demanded as a reference by civil society, eager to make itself heard in the public policymaking environment. Delmas \& Young (2009) define the concept of governance as a contemporary need, given the interaction between human actions and, in the case of the environment, the perceived inability of the state to provide the answers that the environmental crisis requires.
The concept of governance has a clear goal, which is to promote a change in the socio-environmental scenario. In this sense, the governance presented here can also be characterized as a result of a different quality of the Habermasian New Public Sphere (Habermas, 1984), because it is not only expressing the desire of large parts of society for their rights, but it is a condition for facing contemporary problems of a different modernity (Beck, 1997; Beck, 2007).

For Biermann et al. (2009) governance often creates conditions for new institutional spaces and relationships between experts and lay people, technicians and users, and between the public and private sectors. Within governance processes, the more social actors from different sectors interact within a collaborative space, the greater the possibility that the process will have more capillarity, social participation, and effective results, since it is expected that all those involved in the process are committed to the results produced (Lemos \& Agrawal, 2006). Participation, in this sense, is seen as an instrument through which groups affected by a given situation and/or reached by decisions can contribute to finding solutions to problems that need a collective response. Reflexivity within this context is related to the ability of individuals and institutions to function as deliberate, self-critical agents of change in social-ecological systems. For Dryzek \& Pickering $(2017$, p. 1) reflexivity emphasizes the specific implications for institutional change in a context where linkages and feedbacks between human and non-human systems flow, thus "including the need to monitor the impacts of institutions on ecosystems and vice versa, and to rethink and reshape core values and practices accordingly". 
Considering the original work on 'reflexive modernization' (Beck et al., 1997), our understanding is that reflexivity through which individuals and institutions are transformed in response to new challenges and processes require innovative actions to overcome the existing detrimental effects of environmental degradation.

We understand "reflexive governance" as used to define possible governance arrangements where "either institutions allow for reflexive adaptation of rules and procedures or where the governed have some capacity to affect the construction of governance objects" (Feindt \& Weiland, 2018, p.663).

Environmental governance, specifically, can be considered as a "set of regulatory processes, mechanisms, and organizations through which political actors influence environmental actions and outcomes" (Lemos \& Agrawal, 2006, p. 298) or a set of deliberative measures taken to prevent, reduce, or mitigate environmental damage (Driessen et al., 2012). Cooperation and coordination, and how institutions and practices can productively respond to changing social-ecological conditions, especially when those changes are capable of producing catastrophe, are important concerns in the field of environmental governance (Dryzek \& Pickering, 2017).

According to Ivanova (2005), the concept of environmental governance opens up a stimulating space to think about innovative ways of managing natural resources, since they are part of the governance system, which includes:

(1) the political element, which consists of balancing the various interests and political realities; and
(2) the credibility factor, related to the instruments supporting the policies that make people believe in them and in the environmental dimension.

As such, multi-stakeholder participation, engagement and negotiation, as well as decentralization (transfer of power to local government) and conflict resolution mechanisms can be seen as building blocks of environmental governance (Jacobi, 2012; Pahl-Wostl, 2012). For Ostrom (2009), the search for solutions to environmental issues should involve public and private institutions at higher levels, such as federal systems, which can act in partnership and collaboration with medium- and small-scale organizations at regional and local levels. Finding the necessary answers to problems that involve collective interest, sustainability, uncertainty, and risk is, therefore, far from trivial; it demands reflection, innovation and collaboration between private and public institutions, which, more often than not, can complement each other.

Young (2005) points out that institutionalizing solutions to environmental problems has proven to be an effective way to deal with the complexity of issues addressed by governance practices. Institutionalization can occur in the form of incentives, so that certain social actors take on a certain practice, which can positively impact the quality of a particular ecosystem resource, or neutralize behaviors that produce unwanted environmental effects. The main challenge, however, is to articulate the complex interdependencies of institutions, actors, and feedbacks in the environmental system. Meeting this challenge requires an adaptive governance approach - an emerging form of environmental governance (Pahl-Wostl, 2015; Pahl-Wostl, 2017; Yasmin et al., 2020). 
In the context of adaptive environmental governance, Chaffin et al. (2014) present a stimulating synthesis on new theoretical approaches to managing uncertainty and complexity, emphasizing the work of the most renowned authors who consider that uncertainties associated with global environmental change and that climate change and significant transformations in environmental governance demand to be highly adaptive (Young \& Gasser, 2002; Folke et al., 2005; Young, 2005; Young, 2013; Folke, 2016). In this context, one of the main challenges is to seek solutions to highly contextualized situations while expanding coordinated initiatives across large-scale ecosystems that cross multiple jurisdictional boundaries (Lemos \& Agrawal, 2006).

One way to address this issue is sought in the numerous bottom-up approaches to promote governance configurations through agendas developed by local actors, social networks, and different collaborative dynamics that represent alternatives to environmental decision making within the complex dynamics of natural resource management (Chaffin et al., 2014). However, decentralized or polycentric governance arrangements require a complex combination of multiple levels and diverse types of organizations drawn from the public, private, and social sectors; they also imply the existence of multiple centers of decision-making and coordination by a global system of rules (Mcginnis \& Ostrom, 2014). The challenge is therefore to coordinate different modes of governance that exist within a given level with those that exist between different levels of government, and to accommodate a reflexive inter-level dynamic that can promote transgressive thinking - in order to overcome social patterns and institutional arrangements that impede sustainabi- lity - with a cooperative approach to developing jointly designed sustainable futures scenarios.

In this sense, the diversification of strategies to improve natural resource management and achieve sustainable development (Folke et al., 2005) implies, according to Pahl-Wostl et al. (2007), enabling participation and collaboration at different scales, within a reflexivity approach, and strengthening social networks. According to Yasmin et al. (2020) this has expanded the dialogue among multiple resource users, contributing to:

(1) integrated management practices;

(2) adaptive capacity to deal with uncertainty;

(3) more flexible institutions; and

(4) the establishment of social networks in multi-level governance systems associated with improved adaptive capacity and governance (Armitage et al., 2009; Berkes, 2009; Pahl-Wostl, 2009; Plummer, 2009).

The authors have systematized several approaches that imply different dynamics to promote multiple interactive frames, such as: adaptive co-management (Olsson, et al., 2004), co-learning processes (Armitage et al., 2009), collaborative governance (Ansell \& Gash, 2008), multi-level learning frameworks (Pahl-Wostl, 2009), and design principles for adaptive institutions (Huntjens et al., 2012).

Pahl-Wostl (2009) also emphasizes the importance of participatory and networked approaches as facilitators of the engagement of local stakeholder groups and their integration of knowledge and experience, which results in better informed decision-making and social learning processes that can potentially support the design of solutions that lead 
to more sustainable outcomes. This fact reveals that one of the key aspects of governance regimes in the context of complex socio-environmental issues is the diverse roles played by non-state actors and the importance of strengthening the role of civil society within participatory approaches (Pahl-Wostl, 2007; Pahl-Wostl, 2009).

The engagement of civil society in governance processes has become not only a reference point for the expansion and strengthening of democratic mechanisms, but also a way to ensure the efficient execution of public policies. Moreover, the expansion of the public sphere has placed a demand on society in terms of gaining greater influence over the state, assuming that social autonomy implies transcending asymmetries in social representation, as well as modifying social relations in favor of greater social self-organization (Jacobi et al., 2018). In this context, it is important to remember Putnam (1995), who highlights the relevance of social practices that build citizenship as a way to constitute a privileged space to cultivate personal responsibility, mutual obligation, and voluntary cooperation.

In this context of broadening participation and promoting decentralized or polycentric governance systems within a reflective stance, we highlight the importance of combining different knowledge systems and adaptive management practices through multi-level governance systems and cycles of "learning by doing" (Kolb, 2014) and social learning oriented practices, which will have to respond to growing uncertainty and unexpected changes in socio-environmental systems. Furthermore, interaction between organizational levels can promote learning and increase the diversity of response options, allowing the system to have greater flexibility and capacity to respond to environmental challenges (Pahl-Wostl et al., 2012).

The effective implementation of instruments of participation and dialogue interaction can establish changes in the patterns of environmental governance, and new mediations between the state and civil society can promote improvements in the dynamics of democratic arenas. In this sense, the creation of meaningful multiple-stakeholders dialogue enacted by social learning processes within environmental governance systems, as well as the reduction of asymmetries of participation in public sector management are key to promote more reflective interactions and conditions to critically evaluate the ability of the environmental governance system itself to accommodate innovative sustainable solutions. Such dialogical processes can support collective learning through which participants can broaden their own perspectives by exposing themselves to and interacting with a diversity of experiences, ideas, and values divergent from each other, potentially creating innovative knowledge based on integrating this diversity in an enriching way (Loeber et al., 2007). This can also contribute to strengthening the cooperative logic between civil society, scientists, experts and technicians. From this perspective, the pursuit of reflexivity in the context of environmental governance can benefit greatly from approaches such as social learning, which can be defined as a semi-structured framework for guiding meaningful and reflexive interactions between representatives of the different social actors involved in participatory arenas, as discussed in the following section. 


\section{Social learning-oriented practices: expanding reflexivity within environmental governance}

The complex and multifaceted constitution of social-natural systems has stimulated theorists and practitioners to apply a wide range of approaches and models to respond to the growing demand for more sustainable natural resource management practices and desirable behavioral changes (e.g. Webler et al., 1995; Röling, 2002). The necessary cultural transformation must bridge the gap between the recognition of the social and environmental crisis and the effective construction of practices capable of structuring new bases for a sustainable society. This alerts to the importance of strengthening communities of practice and social learning as processes and spaces/times that allow:

(1) the expansion of the number of people in the exercise of this knowledge; and (2) the improvement of communication between people as a way to improve social interactions and bring substantial advances in the production of new repertoires and social mobilization to advance sustainability practices (Glasser, 2007; Sterling, 2007; Wenger, 1998).

Social learning is considered here as a process and an approach that can facilitate cultural change (Sterling, 2007). According to Tilbury (2007), three key aspects derive from the notion of social learning for sustainability:

(1) the need to challenge mental models;

(2) employing new approaches to help explore and build skills that promote change; and
(3) the use of pluralism and diversity of viewpoints in joint explorations toward sustainable solutions.

Social learning is directed toward solving real problems in specific contexts, and takes place in groups or communities operating in new, uncertain, and unpredictable circumstances (Wildemeersch, 2007). It indicates the learning processes of individuals and groups that, through social interactions, enable the acquisition of new ways of understanding and problem solving. It is about collaboration among different social actors, involves dialogue building, critical thinking, and creating connections and networks in the search for solutions for sustainability (Jacobi, 2005). The social learning approach brings together various methods of collaborative action and participatory democratic decision-making as an important response to the failures of command-and-control strategies (Collins \& Ison, 2006). In the context of environmental governance, social learning is considered as a useful analytical and facilitative framework for decision making and collective action in complex resource management environments. Such learning can thus be considered as an active part of an intellectual process, based on dialogue and interaction, in a constant movement of recreation and reinterpretation of information, concepts, and meanings. Its innovative perspective refers to the way the object of research or the issue at stake is understood, and the dynamics that are established among the social actors who propose a new way of integrating and articulating knowledge. Social learning seeks to overcome reductionism and encourages doing and thinking about environmental issues in a way that is directly linked to the dialogue between knowledge, participation, and ethical 
values, as fundamental elements to strengthen the complex interaction between society and nature (Jacobi, 2012). By interfering with the learning process and the perceptions and representations of individuals and groups, which have an effect on concrete everyday practices and the environment, social learning provides the tools to build knowledge and innovative interactions that can lead to a more sustainable society.

Social learning practices aim, therefore, to create conditions for the exchange of knowledge, the development of shared goals, collective action, and the co-creation of solutions through dialogical spaces (Muro \& Jeffrey, 2008). Through dialogic practices, it denotes a process of learning transformation/transition that contemplates changes at the level of beliefs, values, and practices of individuals and social groups (Macintyre et al., 2018). Social learning requires that participants are able and willing to communicate as equals and are open to the diversity of viewpoints within the group so that disagreements and conflicts can act as driving forces for collective learning (Wals \& Bawden, 2000). Therefore, the maximum representation of diversity and participation guided by a cooperative vision is emphasized in such processes (Jacobi, 2012). However, the unfolding of social learning processes depends on the presence of interdependent and interconnected factors, among them: equal access to information; facilitation; diversity of participants; trust; and network building (Ernst, 2019).

The type of dialogue desirable to social learning can happen spontaneously or can be promoted and/or enhanced through the design and planning of the interaction (Wals, 2009). There are several tools that essentially propose structures for participation, interaction and dialogue construction, acting on specific situations and issues. Such tools can facilitate the production of outcomes and solutions emerging from the proposed dynamics. They can contribute to the development of individual and collective capacities to solve complex problems faced in social learning processes (Jacobi, 2011). Among several participatory tools available, the World Café (Brown \& Isaacs, 2005), Open Space (Owen, 1997), Improvisation Games (Gerard, 2005), Participatory Diagnosis, Diagnostic Walk, Talking Map (Jacobi, 2011) can be mentioned as examples. Their choice will depend on the context and nature of the problem and the stage in the process. It is notable, however, that such tools should not be seen as resources that can solve the problems at hand, and will not be suitable for all types of groups, and may also be inappropriate to a particular political, social, and economic context (Wals \& Schwarzin, 2012).

According to Wals et al. (2009), it is difficult to characterize purely isolated sequential phases of a social learning process, as its activities interrelate and overlap. Although it is possible to identify important steps that can help in its structure. In summary, a first step would be to identify key players, establishing a core group and identifying key issues to be addressed in connection with the participants' experiences and knowledge in order to increase their sense of purpose and motivation. An activation phase follows as a stage in which more people can be engaged as co-sponsors of the process. At this point, the diversity of knowledge and insights increases, enriching the process and expanding the possibilities for challenging personal assumptions while moving forward on solutions and actions. The design phase of a solution comprises the selection of directions that reflect the group's shared view of the issues at stake. Then the 
implementation phase of the selected solution can take place. Evaluation, however, should ideally be conducted throughout the process, focusing on both the learning process and the implemented solution.

These collective learning processes are argued to support reflective practices and co-creative environments that have the potential to bring about innovative ideas and solutions, as well as collective commitments and sustainability-oriented citizenship practices (Souza et al., 2019). Nevertheless, Glasser (2007) emphasizes that it is still a great challenge to create opportunities for active social learning in which there is a real involvement of the subjects in dialogic relationships that encourage: the perception of the diversity of opinions and worldviews; the mediation of individual and collective interests; and the possibility of expanding repertoires that increase the ability to contextualize and reflect on a problem. Furthermore, social learning cannot be taught by someone outside the context, for it is the practical co-reflection among all parties involved that allows for joint learning and intervention (Wals et al., 2009).

Ernst (2019) demonstrates that social learning is used as an analytical concept to examine social processes or is applied as a tool within environmental governance systems. Several authors elaborate on social learning, indicating that this approach enables capacity building, knowledge integration, adaptive management (Westberg \& Polk, 2016), and change in governance systems (Armitage et al., 2009). Moreover, the increasing involvement and co-learning of the entities involved in management reinforces the dimension of participation, sharing and co-responsibility to decide which sustainability scenarios are desired. Taking into account its context, it also leads to a deeper understanding of the complexity of the socio-environmental issues that need to be addressed. A deeper understanding of a given problem presupposes that social actors share their individual understanding, connect different points of view, and create intersectorial and interdisciplinary dialogues on strengthening the logics of cooperation, within an interactive social structure that we can call a "community of practice" (Wenger, 1998).

Within environmental governance processes, social learning practices open an innovative and interactive space that allows for joint learning and reflexivity about governance conditions (Wals, 2007; Scholzet al., 2014). This collective learning dynamic allows for the improvement of environmental management practices and increases the capacity of actors to respond more adequately to sustainability challenges and integrate natural resource management interfaces - which presupposes the contribution of different fields of knowledge within an interdisciplinary framework.

In the context of multi-level environmental governance systems, it is also important to note the notion of multi-cycle social learning, which has been observed as key to dealing with complex problems that require increased capacity building and the implementation of integrated, innovative and creative actions (Pahl-Wostl, 2009; Pahl-Wostl et al., 2013; Pahl-Wostl, 2018; Pahl-Wostl, 2019). This notion encompasses, in addition to learning processes that occur in groups, an understanding of the shortcomings of institutions and governance mechanisms that also determine the possibilities for social change (Medema et al., 2014). This conception conveys that social learning processes present relationships that unfold horizontally-between local actors - and vertically - in organizations, 
institutions and knowledge systems. The single, double and triple learning cycles are part of the multi-cycle social learning process and are influenced by the levels of governance in which they are embedded (either at the macro level associated with governance regimes and power structures; at the meso level, which is connected to actor networks, and at the micro level, related to the processes among participating stakeholders).The first looping is about improving things without questioning the underlying beliefs and assumptions; the double looping cycle in turn challenges those aspects, and the triple looping looks at the learning process itself and the values and paradigms that guide learning and decision making, probably reaching the level of institutional change (Medema et al., 2014).

In summary, social learning involves the development of new relational capacities both among social agents in the form of learning to collaborate and understand the different roles and capacities of others, and between socio-ecological systems (Pahl-Wostl et al., 2007); in this way, it contributes to the construction of reflexive skills of stakeholders interacting within environmental governance networks. The establishment of social spaces that support and encourage the experience of thinking and acting together in a dialogical, supportive, and ecologically systemic way creates fertile soil for a culture of participation and, consequently, for the construction of new governance potentials (Jacobi, 2012). This paradigmatic shift implies the transformation of perceptions and values, generating a solidary knowledge and complex thinking, open to uncertainty, change, diversity, and the possibility of building and rebuilding, in a continuous process, new readings, interpretations, and possibilities for action and environmental governance.

\section{Conclusion}

The creation of spaces of coexistence, intertwined by the experience of thinking and acting in a dialogical, solidary and ecologically systemic way, can create conditions to promote a culture of participation and, consequently, new spaces of democratic governance of natural resources. In this context, the social learning approach focuses not only on acquiring complementary knowledge and improving understanding of complex interrelated socio-environmental problems, but also on enabling different stakeholders to better understand each other's perceptions of the issues in order to improve stakeholder relationships and provide the basis for consistent, reflective, and articulated cooperation. This approach increases the potential for strengthening spaces for horizontal dialogue, learning, and the exercise of participatory democracy, mediating interactions between diverse social actors who come together collective efforts to build a sustainable future.

This may imply a cultural transformation necessary to bridge the gap between the recognition of the social and environmental crisis and the practices capable of structuring the foundations of a sustainable society. Thus, it requires the strengthening of communities of practice and social learning as processes and spaces/times that promote the expansion of the number of peers in the appropriation of knowledge, and cross-fertilization in order to enhance interactions that bring substantial advances in the production of new repertoires and practices of social mobilization for sustainability.

The space for debate and interaction inherent in environmental governance configurations can 
benefit from the social learning approach, as this implies expanded systems thinking, greater critical reflection, and increased relational capacity of participants to deal with unexpected changes and uncertainties in a context of complexity and escalating socio-environmental problems. Cultivating social learning within environmental governance systems requires, however, that participants are willing to facilitate and interact in an environment of dialogue, as well as work together horizontally to define common goals and strategies. Although social learning processes occur primarily through face-to-face interaction, they can unfold and impact multiple levels of governance. Thus, stakeholders who engage in reflective practices, such as those advocated by social learning, are not only working in coordination, they are interacting in ways that allow critics and change in the very systems they navigate to foster environmental governance arrangements that can effectively promote sustainability practices.

It should be noted that it is not a simple task to recognize certain technical issues for decision making. Understanding a problem presupposes that actors begin to share their acceptance of it, exploring the possibilities of perspectives for intervention. This results in the development of connecting activities to merge diverse types of recognition of a given issue, creating some kind of intersection, the basis for an arena of dialogue and negotiation. Convincing leadership participation and facilitation are essential aspects of building and maintaining the commitment of actors directly or indirectly involved in environmental governance. Instead of control strategies, there is a need for flexible and adaptive management changes, where arenas based on social learning and cooperation become essential for actors' strategic proposals.
The "collective doing" within a learning-oriented environment can be an innovative element in environmental governance pacts, promoting the emergence and understanding of new paradigms that can inform new choices by public authorities and society in a perspective of advancing toward social and environmental sustainability outcomes. Dialogical interactions and authentic communication between stakeholders, as advocated by the social learning approach, is to lead to a shared responsibility for the outcomes and drive the possibility of promoting a legitimate process. The challenge, however, is to negotiate different points of view and effectively communicate the ideas and worldviews of stakeholders in a way that participants can co-learn and challenge their assumptions as they respond to complex situations and the numerous dilemmas of environmental governance on a democratic basis.

We understand that the biggest challenge of reflexivity in environmental governance is to create opportunities for active social learning, in which there is a real involvement of individuals in dialogic relations that favor: the perception of the diversity of opinions and worldviews; the mediation of individual and collective interests; and the possibility of expanding repertoires that expand their capacity to contextualize and reflect. The creation of spaces of conviviality, interwoven with the experience of thinking and acting in a dialogical, solidary and ecologically systemic form, thus creates fertile soil for promoting a culture of participation and consequently, for the building new potentials of democratic governance of natural resources. 


\section{References}

Ansell, C.; Gash, A. Collaborative governance in theory and practice. Journal of Public Administration Research and Theory, 18(4), 543-571, 2008. doi: 10.1093/jopart/mum032

Armitage, D. R.; Plummer, R.; Berkes, F.; Arthur, R. I.; Charles, A. T.; Iain, J.; Davidson-Hunt, A. Diduck, A.P.; Doubleday, N.C.; Johnson, D.S.; Marschke, M.; McConney, P.; Pinkerton, E.W.; Wollenberg, E. K. Adaptive co-management for social-ecological complexity. Frontiers in Ecology and the Environment, 7(2), 95-102, 2009. doi: $10.1890 / 070089$

Beck, U. A reinvenção da política. In: Beck, U.; Giddens, A.; Lash, S. (Eds.). Modernização reflexiva: política, tradição e estética na ordem social moderna. São Paulo: Editora da Universidade Estadual Paulista, p. 1-53, 1997.

Beck, U.; Giddens, A.; Lash, S. Modernização reflexiva: política, tradição e estética na ordem social moderna. São Paulo: Editora da Universidade Estadual Paulista, 1997.

Beck, U. World at risk. United Kingdom: Polity Press, 2007.

Berkes, F. Evolution of co-management: role of knowledge generation, bridging organizations and social learning. Journal of Environmental Management, 90(5), 1692-1702, 2009. doi: 10.1016/j.jenvman.2008.12.001

Biermann, F.; Betsill, M.; Gupta, J.; Kani, N.; Lebel, L.; Liverman, D.; Chroeder, H.; Siebenhüner, B. Earth System Governance: People, Places and the Planet. Science and Implementation Plan of the Earth System Governance Project. Bonn: International Human Dimensions Programme on Global Environmental Change (IHDP), 2009.

Brown, J.; Isaacs, D. The world cafe book: shaping our futures through conversations that matter. San Francisco: Berrett-Koehler Publishers, 2005.

Chaffin, B. C.; Gosnell, H.; Cosens, B. A decade of adaptive governance scholarship: Synthesis and future directions. Ecology and Society, 19(3), 56, 2014. doi: 10.5751/ES06824-190356

Collins, K.; Ison, R. Dare we jump off Arnstein's ladder? Social learning as a new policy paradigm. In: Proceedings of
Participatory Approaches in Science \& Technology (PATH) Conference. Edinburgh, 4th-7th jun., 2006.

Delmas, M. A.; Young, O. R. Introduction: new perspectives on governance for sustainable development. In: Delmas, M. A.; Young, O. R. (Eds.). Governance for the Environment: New Perspectives. Cambridge: Cambridge University Press, p. 3-11, 2009.

Driessen, P. P. J.; Dieperink, C.; Laerhoven, F; Runhaar, H. A. C.; Vermeulen, W. J. V. Towards a conceptual framework for the study of shifts in modes of environmental governance - Experiences from The Netherlands. Environmental Policy and Governance, 22(3), 143-160, 2012. doi: 10.1002/eet. 1580

Dryzek, J. S.; Pickering, J. Deliberation as a catalyst for reflexive environmental governance. Ecological Economics, 131(C), 353-360, 2017.

Ernst, A. Review of factors influencing social learning within participatory environmental governance. Ecology and Society, 24(1), 3, 2019. doi: 10.5751/ES-10599-240103

Feindt, P. H.; Weiland, S. Reflexive governance: exploring the concept and assessing its critical potential for sustainable development. Introduction to the special issue. Journal of Environmental Policy \& Planning, 20(6), 661-674, 2018. doi: 10.1080/1523908X.2018.1532562

Folke, C.; Hahn, T.; Olsson, P.; Norberg, J. Adaptive Governance of Social-Ecological Systems. Annual Review of Environment and Resources, 30(1), 441-473, 2005. doi: 10.1146/annurev.energy.30.050504.144511

Folke, C. Resilience (Republished). Ecology and Society, 21(4), 44, 2016. doi: 10.5751/ES-09088-210444

Glasser, H. Minding the gap: the role of social learning in linking our stated desire for a more sustainable world to our everyday actions and policies. In: Wals, A. E. J. (Ed.). Social learning towards a sustainable world: principles, perspectives, and praxis. The Netherlands: Wageningen Academic Publishers, p. 35-62, 2007.

Gerard, G. Creating new connections: dialogue and improvisation. In: Banathy, B. H.; Jenlink, P. M. (Eds.). Dialogue as a means of collective communication. New York: Kluwer Academic/Plenum Press, 2005. 
Habermas, J. Mudança estrutural da esfera pública. Rio de Janeiro: Tempo Brasileiro, 1984.

Huntjens, P.; Lebel, L.; Pahl-Wostl, C.; Camkin, J.; Schulze, R.; Kranz, N. Institutional design propositions for the governance of adaptation to climate change in the water sector. Global Environmental Change, 22(1), 67-81, 2012. doi: 10.1016/j.gloenvcha.2011.09.015

Ivanova, M. Environment: The path of global Environmental Governance - Form and Function in Historical Perspective. In: Ayre, G.; Callway, R. (Eds.). Governance for sustainable development: a foundation for the future. Londres: Earthscan Publications, p. 45-72, 2005.

Jacobi, P. R. Educação ambiental: o desafio da construção de um pensamento crítico, complexo e reflexivo. Educação e Pesquisa, 31(2), 233-250, 2005. doi: 10.1590/S151797022005000200007

Jacobi, P. R. Sustentabilidade, participação, aprendizagem social. In: Jacobi, P. R. (Org.). Aprendizagem Social: diálogos e ferramentas participativas, aprender junto para cuidar da água. São Paulo: Instituto de Energia e Ambiente - Universidade de São Paulo, p. 11-21, 2011.

Jacobi, P. R. Governança ambiental, participação social e educação para a sustentabilidade. In: Philippi, A. J.; Sampaio, C. A. C.; Fernandes, V. (Orgs.). Gestão da Natureza Pública e Sustentabilidade. São Paulo: Manole, p. 342-361, 2012.

Jacobi, P. R.; Bujak, N. L.; Souza, A. N. Pénurie hydrique et crise de gouvernance dans la Région métropolitaine de São Paulo. Brésil(s) - Sciences Humaines et Sociales, 13, 2018. doi: 10.4000/bresils. 2506

Loeber, A. Mierlo, B.; Grin, J.; Leeuwis, C. The practical value of theory: conceptualizing learning in the pursuit of a sustainable development. In: Wals, A. E. J. (Ed.). Social Learning towards a sustainable world: principals, perspectives and praxis. The Netherlands: Wageningen Academic Publishers, p. 83-99, 2007.

Kolb, D. A. Experiential learning: Experience as the source of learning and development. New Jersey: FT Press, 2014.

Lemos, M. C.; Agrawal, A. Environmental Governance. Annual Review of Environment and Resources, 31(1), 297 -
325, 2006. doi: 10.1146/annurev.energy.31.042605.135621

Macintyre, T.; Lotz-Sisitka, H.; Wals, A.; Vogel, C.; Tassone, V. Towards transformative social learning on the path to 1.5 degrees. Current Opinion in Environmental Sustainability, 31, 80-87, 2018. doi: 10.1016/j.cosust.2017.12.003

McGinnis, M. D.; Ostrom, E. Social-ecological system framework: initial changes and continuing challenges. Ecology and Society, 19(2), 30, 2014. doi: 10.5751/ES06387-190230

Medema, W.; Wals, A.; Adamowski, J. Multi-loop social learning for sustainable land and water governance: towards a research agenda on the potential of virtual learning platforms. NJAS: Wageningen Journal of Life Sciences, 69, 23-38, 2014. doi: 10.1016/j.njas.2014.03.003

Muro, M.; Jeffrey, P. A critical review of the theory and application of social learning in participatory natural resource management processes. Journal of Environmental Planning and Management, 51(3), 325-344, 2008. doi: $10.1080 / 09640560801977190$

Olsson, P.; Folke, C.; Berkes, F. Adaptive Co-management for Building Resilience in Social-Ecological Systems. Environmental Management, 34(1), 75-90, 2004. doi: 10.1007/ s00267-003-0101-7

Ostrom, E. A Polycentric approach for coping with climate change. World Bank Group, 2009. doi: 10.1596/18139450-5095

Owen, H. Open space technology: a user's guide. San Francisco: Berrett-Koehler Publishers, 1997.

Pahl-Wostl, C. Transitions towards adaptive management of water facing climate and global change. Water Resources Management, 21(1), 49-62, 2007. doi: 10.1007/s11269006-9040-4

Pahl-Wostl, C. A conceptual framework for analysing adaptive capacity and multi-level learning processes in resource governance regimes. Global Environmental Change, 19(3), 354-365, 2009. doi: 10.1016/j.gloenvcha.2009.06.001

Pahl-Wostl, C. Water governance in the face of global change: from understanding to transformation. Switzerland: Springer International Publishing, 2015. 
Pahl-Wostl, C. An evolutionary perspective on water governance: from understanding to transformation. Water Resources Management, 31(10), 2917-2932, 2017. doi: 10.1007/s11269-017-1727-1

Pahl-Wostl, C. Governance of the water-energy-food security nexus: a multi-level coordination challenge. Environmental Science \& Policy, 92, 356-367, 2018. doi: 10.1016/j. envsci.2017.07.017

Pahl-Wostl, C. The role of governance modes and meta-governance in the transformation towards sustainable water governance. Environmental Science \& Policy, 91, 6-16, 2019. doi: 10.1016/j.envsci.2019.10.008

Pahl-Wostl, C.; Becker, G.; Knieper, C.; Sendzimir, J. How multilevel societal learning processes facilitate transformative change: a comparative case study analysis on flood management. Ecology and Society, 18(4), 2013. doi: 10.5751/ES-05779-180458

Pahl-Wostl, C.; Lebel, L.; Knieper, C.; Nikitina, E. From applying panaceas to mastering complexity: toward adaptive water governance in river basins. Environmental Science \& Policy, 23, 24-34, 2012. doi: 10.1016/j.envsci.2012.07.014

Pahl-Wostl, C.; Sendzimir, J.; Jeffrey, P.; Aerts, J.; Berkamp, G.; Cross, K. Managing change toward adaptive water management through social learning. Ecology and Society, 12(2), 30, 2007. doi: 10.5751/ES-02147-120230

Plummer, M. L. Assessing benefit transfer for the valuation of ecosystem services. Frontiers in Ecology and the Environment, 7(1), 38-45, 2009. doi: 10.1890/080091

Putnam, R.D. Bowling Alone: America's declining social capital. Journal of Democracy, 6(1), 65-78, 1995. doi:10.1353/ jod.1995.0002.

Röling, N. Beyond the aggregation of individual preferences: moving from multiple to distributed cognition in resource dilemmas. In: Leeuwis, C.; Pyburn, R. (Eds.). Wheelbarrows full of frogs: social learning in rural resource management. The Netherlands: Koninklijke van Gorcum, p. 25-47, 2002.

Scholz, G.; Dewulf, A.; Pahl-Wostl, C. An analytical framework of social learning facilitated by participatory methods. Systemic Practice and Action Research, 27(6),
575-591, 2014. doi: 10.1007/s11213-013-9310-z

Souza, D. T.; Wals, A. E. J.; Jacobi, P. R. Learning-based transformations towards sustainability: a relational approach based on Humberto Maturana and Paulo Freire. Environmental Education Research, 25(11), 1605-1619, 2019. doi: 10.1080/13504622.2019.1641183

Sterling, S. Riding the storm: towards a connective cultural consciousness. In: Wals, A.E.J. (Ed.). Social Learning towards a sustainable world: principals, perspectives and praxis. The Netherlands: Wageningen Academic Publishers, p. 63-82, 2007.

Tilbury, D. Learning based change for sustainability: perspectives and pathways. In: Wals, A.E.J. (Ed.). Social Learning towards a sustainable world: principals, perspectives and praxis. The Netherlands: Wageningen Academic Publishers, p. 117-132, 2007.

Wals, A. E. J. (Ed.). Social learning towards a sustainable world: principals, perspectives and praxis. The Netherlands: Wageningen Academic Publishers, 2007.

Wals, A. E. J.; Bawden, R. Integrating sustainability into agricultural education: dealing with complexity, uncertainty and diverging worldviews. Wageningen: ICA, 2000.

Wals, A. E. J.; Hoeven, N. van der; Blanken, H. The acoustics of social learning: designing learning processes that contribute to a more sustainable world. The Netherlands: Wageningen Academic Publishers, 2009.

Wals, A.E.J.; Schwarzin, L. Fostering organizational sustainability through dialogic interaction. The Learning Organization, 19(1), 11-27. 2012. doi: 10.1108/09696471211190338

Webler, T.; Kastenholz, H.; Renn, O. Public participation in impact assessment: A social learning perspective. Environmental Impact Assessment Review, 15(5), 443-463, 1995. doi: 10.1016/0195-9255(95)00043-E

Wenger, E. Communities of Practice: Learning, Meaning, and Identity.Cambridge: Cambridge University Press, 1998.

Westberg, L.; Polk, M. The role of learning in transdisciplinary research: Moving from a normative concept to an analytical tool through a practice-based approach. Sustainability Science, 11(3), 385-397, 2016. doi: 10.1007/ s11625-016-0358-4 
Wildemeersch, D. Social Learning Revisited: Lessons Learned from North and South. In: Wals, A.E.J. (Ed.). Social Learning towards a sustainable world: principals, perspectives and praxis. The Netherlands: Wageningen Academic Publishers, p. 99-116, 2007.

Yasmin, T.; Farrelly, M.; Rogers, B. C. Adaptive governance: a catalyst for advancing sustainable urban transformation in the global South. International Journal of Water Resources Development, 36(5), 818-838, 2020. doi: 10.1080/07900627.2019.1611548

Young, O. R.; Gasser, L. The institutional dimensions of environmental change: fit, interplay, and scale. Massachusetts: MIT Press, 2002.
Young, O. R. Why is there no unified theory of environmental governance? In: Dauvergne, P. (Ed.). Handbook of Global Environmental Politics. Cheltenham: Edward Elgar Publishing, p. 170-184, 2005.

Young, O. R. Sugaring off: enduring insights from long-term research on environmental governance. International Environmental Agreements: Politics, Law and Economics, 13(1), 87-105, 2013. doi: 10.1007/s10784-012-9204-z. 